\title{
Integritas Kepemimpinan
}

\section{Antikorupsi di Sektor}

\section{Kesehatan}

\section{DUMILAH AYUNINGTYAS, SITI KHODIJAH PARINDURI, DAN FITRIA ARYANI SUSANTI}

Universitas Indonesia

dumillah@gmail.com

sikho.parinduri@gmail.com

fitriaaryanisusanti@yahoo.com

p-ISSN: $2477-118 \mathrm{X}$

e-ISSN: 2615-7977

\section{A B S T RAK}

Kesehatan amat strategis dan berperan penting dalam menentukan kesejahteraan penduduk Indonesia. Anggaran untuk kesehatan dalam Anggaran Pendapatan dan Belanja (APBN) 2017 sebesar Rp 104 triliun, bahkan meningkat Rp 500 miliar dari ajuan RAPBN 2017. Besarnya anggaran di sektor kesehatan membuka peluang disalahgunakan oleh instansi maupun individu terkait. Studi ini bertujuan menganalisis konsep dan implementasi integritas kepemimpinan antikorupsi di sektor kesehatan. Penelitian dilakukan dengan pendekatan kualitatif untuk menggali pandangan stakeholder di sektor kesehatan dan menetapkan fenomena tematik dari analisis isi (content analysis) hasil wawancara. Hasil penelitian mendapatkan adanya keprihatinan yang sama tentang kejadian korupsi di sektor 
kesehatan seperti halnya sektor lain. Karena itu, menjadi sangat relevan untuk menyiapkan para pemimpin dengan kompetensi kepemimpinan antikorupsi di sektor kesehatan. Peraturan acuan untuk penerimaan pegawai, penilaian dan penempatan pejabat struktural sektor kesehatan belum secara eksplisit menyatakan kompetensi antikorupsi sebagai bagian dari persyaratan yang harus dimiliki. Konsep kepemimpinan antikorupsi berangkat dari nilai kebermanfaatan, keinginan menolong, dan karakter "amat tangguh"/very strong (keberanian untuk bertindak, mengubah dan menerima risiko sehingga memiliki daya tahan terhadap bujukan maupun dorongan untuk melakukan korupsi). Nilai dan norma tersebut semestinya dinyatakan lebih jelas dalam instrumen kompetensi, meskipun penanamannya harus berlangsung sejak dini dan dibangun dari nilai-nilai keluarga, pendidikan agama, sekolah dan lingkungan pertemanan (peer group). Secara khusus, penetapan seseorang menjadi pemimpin di sektor kesehatan harus mempertimbangkan kompetensi antikorupsi secara komprehensif, antara lain dengan memanfatkan asesmen mulai dari rekam jejak, penilaian rekan kerja dan atasan. Hal penting selanjutnya adalah mengoperasionalkan nilai integritas dan kompetensi antikorupsi tersebut agar lebih terukur dan dapat diaplikasikan.

Kata Kunci: antikorupsi, integritas, kepemimpinan, sektor kesehatan

\section{A B S TRA C T}

Health is very strategic and plays an important role in determining the welfare of the Indonesian population. The budget for health in the 2017 Revenue and Expenditure Budget (APBN) of Rp 104 trillion, even increased by $R p 500$ billion from the draft $R A P B N$ 2017. The amount of budget in the health sector opens opportunities abused by relevant agencies and individuals. This study aims to analyze the concept and implementation of anticorruption leadership integrity in the health sector. The research is conducted with a quali- 
tative approach to explore the views of stakeholders in the health sector and establish the thematic phenomena of content analysis of the interview results. The research finds similar concerns about the incidence of corruption in the health sector as well as other sectors, hence it becomes highly relevant to prepare leaders with the anticorruption leadership competence in the health sector. Reference rules for employee recruitment, appraisal and placement of health sector structural officials have not explicitly stated anti-corruption competence as part of the requirements that must be owned. The concept of anti-corruption leadership stems from the value of usefulness, willingness to help, and "very tough" character (the courage to act, change and accept risks so as to have persistence in persuasion and the drive to corruption). These values and norms should be clearly stated in the competency instruments, although their planting should take place early and be built on family values, religious education, schools, and peer-group environments. Specifically, the determination of a person to be a leader in the health sector must consider the competence of anti-corruption comprehensively, among others, by assessing the assessment starting from the track record, peer assessment and supervisor. The next important thing is to operationalize the value of the integrity and competence of anticorruption to be more measurable and applicable.

Keywords: anti-corruption, integrity, leadership, the health sector

\section{A. PENDAHULUAN}

Sektor kesehatan merupakan sektor strategis dan memiliki andil besar terhadap kesejahteraan penduduk Indonesia dan pencapaian pembangunan manusia yang diukur dengan Indeks Pembangunan Manusia (IPM). Pembangunan kesehatan merupakan salah satu prioritas penting dalam program pemerintah. Hal ini bisa dilihat dari jumlah anggaran di Kementerian Kesehatan yang termasuk dalam jajaran lima besar kementerian/lembaga yang mendapat jatah 
APBN terbesar. Besarnya anggaran yang dimiliki oleh Kementerian Kesehatan menjadi peluang untuk disalahgunakan.

Berbagai penyalahgunaan dan kasus korupsi di sektor kesehatan terjadi pada level pemerintah pusat dan daerah. Menurut majelis hakim, Siti Fadilah Supari terbukti menyalahgunakan wewenang dalam kegiatan pengadaan alat kesehatan (alkes) saat kejadian luar biasa (KLB) tahun 2005, pada Pusat Penanggulangan Masalah Kesehatan (PPMK) Departemen Kesehatan (Kompas, 16/6/2017).

Kondisi tersebut tentu amat ironis, karena jelas bahwa korupsi merupakan penghambat pembangunan negara. Pada skala nasional, korupsi mengakibatkan berkurangnya investasi, menghambat inovasi, dan memperlambat pertumbuhan ekonomi (Kaufmann, 2005). Terlebih lagi pada negara berkembang. Beberapa studi menjelaskan bahwa korupsi membawa negara ke arah kelaparan, kemiskinan, dan memunculkan ketidakstabilan sosial (Otusanya, 2011; Nguyen et al, 2016). Kenyataan yang lebih menyedihkan ditunjukkan oleh Abed et al (2002) dalam Hanf et al (2011) yang mengobservasi adanya hubungan signifikan antara korupsi dengan angka kematian anak. Setidaknya ada 140.000 kematian anak yang berkaitan erat dengan korupsi. Namun sayangnya korupsi dalam bidang kesehatan kerap kali tidak dipedulikan. (Hanf et al, 2011).

Upaya pencegahan korupsi di sektor kesehatan amat penting dan mendesak, karena dampak yang ditimbulkan oleh tindakan korupsi jauh lebih luas dibandingkan bidang lain. Sektor kesehatan memiliki karakteristik tersendiri yang unik, dengan faktor-faktor risiko seperti asimetri distribusi informasi, ketidakpastian mekanisme pasar, dan besarnya pengeluaran publik, serta kompleksitas lain yang menyebabkan rawannya tindakan korupsi. Terlebih lagi sektor kesehatan berkaitan dengan aspek vital kehidupan masyarakat, keadilan dan peme-rataan tanpa mempertimbangkan kondisi dan status finansial individu. Karakter lainnya adalah sifat uncertainty atau ketidakpastian dalam pelayanan kesehatan, karena tidak seorang pun akan tahu kapan ia akan butuh pelayanan rumah sakit dan berapa biaya yang akan ia keluarkan. Pemerintah dituntut memiliki kebijakan pembiayaan kesehatan yang menjamin akses bagi 
masyarakat terhadap pelayanan kesehatan dengan kualitas memadai, terutama bagi masyarakat miskin yang merupakan kelompok rentan. Sebagaimana ungkapan seorang ahli ekonomi sosial dan kesehatan, Gunnar Myrdal, "People become sick because they are poor, and become poorer because they are sick, and become sicker because they are poorer" (orang menjadi sakit karena mereka miskin, dan mereka bertambah miskin karena mereka sakit serta menjadi lebih sakit karena mereka lebih miskin) (Ayuningtyas, 2014).

Pada dasarnya semua komponen masyarakat bertanggung jawab untuk ikut serta dalam penyelesaian berbagai masalah yang melanda bangsa Indonesia, akan tetapi, sosok yang pa-ling bertanggung jawab dan harus berperan aktif adalah pemimpin bangsa (Haikal, 2014). Salah satu faktor yang menjadi penyebab timbulnya korupsi adalah kegagalan para pemimpin bangsa karena ketidakjujuran (integritas) dalam memimpin bangsanya. Oleh karena itu, studi ini bertujuan menganalisis konsep dan implementasi integritas kepemimpinan antikorupsi sektor kesehatan sebagai dasar rekomendasi penguatan upaya pencegahan dan pemberantasan korupsi di lembaga pemerintahan Indonesia.

\section{Tinjauan Teoritis}

\section{a. Pengertian Integritas Kepemimpinan}

Integritas adalah suatu bentuk kualitas yang meliputi kejujuran, kredibilitas dan ketulusan. Dalam konteks kepemimpinan, integritas terwujud dalam cara seorang pemimpin berbicara, mengarahkan dan bereaksi terhadap pengikutnya dan lingkungannya. Ada banyak sekali pengertian kepemimpinan, termasuk nilai kepemimpinan yang khas dan berlaku untuk Indonesia sebagaimana diajarkan oleh Ki Hajar Dewantara dengan tiga prinsip kepemimpinan "ing ngarsa-ing madya dan tut wuri handayani-nya” yang muncul jauh sebelum Blanchard dan Hersey dengan Situasional Leadership-nya. (Fauziah, 2016; Hersey, 1960)

Nilai-nilai kepemimpinan yang bersumber dari ajaran Islam sebagai, “Khadimul Ummat, Imam-Makmum Ro'iy-Rois, Qiyadah- 
Qoid" yang melayani umat, berada di depan sebagai teladan, namun siap pula mengikut kebenaran dari belakang sekalipun, memperkaya dan menguatkan konsep kepemimpinan di Indonesia (Sidiq, 2014). Atau pula pemahaman kepemimpinan sebagai pemupuk perubahan (nurturing change) yang dikenalkan oleh Peter Senge (Senge, 1990). Namun secara umum kepemimpinan dipahami sebagai kemampuan seseorang untuk memengaruhi pihak lain, mengarahkan, memotivasi dan memandu orang lain. Juga, kemampuan dalam memfasilitasi aksi dan memandu perubahan, ataupun kemampuan seseorang dalam menginspirasi pihak lain untuk mengetahui, untuk melakukan atau mewujudkan suatu keinginan.

Memimpin dengan integritas akan menghasilkan ketulusankepercayaan (trustworthinesss) dari pengikutnya (Husain, 2014). Setidaknya terdapat empat perilaku yang perlu diasah dan diperkuat oleh seorang pemimpin untuk menjadi pemimpin yang dapat dipercaya yaitu, keandalan (keep your promise, walk the talk, satu kata dalam perbuatan; keterbukaan untuk terus belajar dari kesalahan perilaku dan memperbaiki diri); penerimaan, yaitu kesadaran diri untuk menerima keadaan orang lain, tidak mendiskriminasi, mendiskreditkan); kejujuran (menyampaikan secara jelas apa yang dimaksudkan dengan nilai-nilai, etika dan keyakinan) (Leadership Inc, 2014). Integritas kepemimpinan karenanya adalah kapasitas kepemimpinan dengan nilai-nilai luhur, kejujuran, keterbukaan yang memungkinkan seseorang berteguh terhadap nilai-nilai kebaikan bersama.

\section{b. Integritas Kepemimpinan di Sektor Kesehatan: Urgensi dan Strategi}

Studi ini menggali dan mengawali dengan merumuskan lebih spesifik konsep integritas kepemimpinan antikorupsi di sektor kesehatan sebagai upaya perubahan sistemik untuk pencegahan antikorupsi. Jeremy Pope (2003) menawarkan enam bidang pokok perubahan yang dapat mendukung pelaksanaan strategi antikorupsi yang menyeluruh, yaitu; kepemimpinan, program publik, perbaikan 
organisasi pemerintah, penegakan hukum, kesadaran masyarakat dan pembentukan lembaga pencegah korupsi. Unsur kepemimpinan empat (4) R, yaitu Renew, Reframe, Restructure, dan Revitalize (Gouillart dan Nelly, 1995) dalam Yuliana (2015) dapat menjadi alternatif karakter dan dasar strategi penguatan integritas kepemimpinan antikorupsi di sektor kesehatan. Keempat komponen tersebut merupakan kesatuan yang dilakukan bersamaan, tidak bagian per bagian, sebagai syarat membangun nilai dan karakter integritas kepemimpinan antikorupsi. Secara ringkas, keempat komponen tersebut dijelaskan berikut ini: a. reframing (perubahan pola pikir, mental model bahkan dapat pula nilai-nilai dan norma untuk mewujudkan visi bersama, b. restructuring (melatih dan menggerakkan seluruh komponen organisasi agar bergerak ke arah yang diinginkan), c. revitalization (membawa kehidupan baru ke dalam organisasi, mengembangkan hal-hal baru untuk menjawab tuntutan stakeholders), d. renewal (membekali diri dengan keterampilan (skills) dan semangat (spirit) yang baru, untuk regenerasi sesuai dengan perkembangan di lingkungan strategisnya.

\section{Metode Penelitian}

Lingkup studi ini menganalisis konsep, aturan tentang integritas serta gambaran implementasi kepemimpinan korupsi di sektor kesehatan sebagai dasar menyusun rekomendasi konsep atau kriteria integritas kepemimpinan antikorupsi di sektor kesehatan di Indonesia. Oleh karena itu studi ini dilakukan sebagai penelitian analitik dengan pendekatan kualitatif yang melakukan penggalian melalui wa-wancara mendalam, mengacu pada pedoman wawancara terstruktur. Informan yang dipilih adalah stakeholder utama di sektor kesehatan yang memenuhi prinsip appropriatness dan adequacy dalam penetapan informan, serta kriteria informan kunci ideal menurut Tremblay, yaitu, Role in community, Knowledge. Willingness, Communicabillity, dan Impartiality. Informan meliputi para ahli di bidang kesehatan dan kebijakan kesehatan serta administrasi dan manajemen perumahsakitan, pimpinan fakultas kesehat- 
an masyarakat juga stakeholder pelaku di sektor kesehatan, yaitu kepala puskesmas, direktur dan manajer rumah sakit umum daerah serta mantan pejabat tinggi Kementerian Kesehatan periode tahun 2004-2009 yang pernah tersangkut korupsi. Di awal studi peneliti telah pula bersurat kepada Badan PPSDM Kementerian Kesehatan untuk izin mewawancarai, namun hingga studi ini berakhir belum mendapatkan jawaban kesediaan dan jadwal wawancara. Daftar informan yang disamarkan mengikuti syarat dalam proses kaji etik tentang anonimitas seperti yang tergambar pada tabel 1:

Tabel 1 . Informan Penelitian Integritas Kepemimpinan Antikorupsi Sektor di Kesehatan

\begin{tabular}{cccc}
\hline No. Informan & $\begin{array}{c}\text { Alasan pemilihan } \\
\text { Informan }\end{array}$ & $\begin{array}{c}\text { Informasi yang } \\
\text { akan digali }\end{array}$ & Keterangan \\
\hline
\end{tabular}

Pakar anan kesehatan

Administrasi dan manajemen dan Ke- keuangan pelayanan

1. bijakan kesehatan yang ban-

Kesehatan, yak terlibat dalam khususnya peningkatan kualitas Perumah- administrasi rumah sakitan sakit yang ada di Indonesia, dewan Pandangan kepemimpinan di sektor kesehatan, korupsi yang terjadi di sektor kesehatan, dan upaya pencegahan korupsi di sektor kesehatan. penasihat rumah sakit.

Pakar kesehatan lapangan di daerah mewakili proyek kesehatan milik Depkes, WHO, USAID, Bank Dunia, ADB, World Vision,

$\begin{array}{lll}\text { 2. } & \text { Pakar } & \text { dan AusAID. Ahli } \\ \text { Kesehatan } & \text { advokasi bidang } \\ & \text { kesehatan, pelopor } \\ & \text { Universal Health } \\ & \text { Coverage Sistem } \\ & \text { Jaminan Sosial } \\ & \text { Nasional (SJSN) di } \\ & \text { Indonesia. pengajar } \\ & \text { mata kuliah pendidi- } \\ & \text { kan antikorupsi. }\end{array}$

Pandangan kasus korupsi di sektor kesehatan, kepemimpinan antikorupsi di sektor kesehatan. 


\begin{tabular}{|c|c|c|c|c|}
\hline 3. & $\begin{array}{l}\text { Pakar } \\
\text { Ekonomi } \\
\text { Kesehatan }\end{array}$ & $\begin{array}{l}\text { Ahli kebijakan dan } \\
\text { ekonomi kesehatan, } \\
\text { pelopor Universal } \\
\text { Health Coverage } \\
\text { Sistem Jaminan So- } \\
\text { sial Nasional (SJSN) } \\
\text { di Indonesia. }\end{array}$ & $\begin{array}{l}\text { Pandangan definisi } \\
\text { korupsi di sektor } \\
\text { kesehatan, faktor } \\
\text { pendorong kasus } \\
\text { korupsi di sektor } \\
\text { kesehatan, dan } \\
\text { kepemimpinan an- } \\
\text { tikorupsi di sektor } \\
\text { kesehatan. }\end{array}$ & \\
\hline 4. & $\begin{array}{l}\text { Pakar } \\
\text { Kebijakan } \\
\text { Kesehatan }\end{array}$ & $\begin{array}{l}\text { Pakar Kebijakan } \\
\text { Kesehatan } \\
\text { dan akademisi } \\
\text { Administrasi dan } \\
\text { kebijakan kesehatan. }\end{array}$ & $\begin{array}{l}\text { Pandangan } \\
\text { definisi korupsi } \\
\text { dan peraturan } \\
\text { dan perundangan } \\
\text { integritas } \\
\text { antikorupsi di } \\
\text { sektor kesehatan. }\end{array}$ & \\
\hline 5. & $\begin{array}{l}\text { Pakar } \\
\text { Kesehatan } \\
\text { Masyarakat } \\
\text { dan Mantan } \\
\text { Pejabat di } \\
\text { Wolrd Health } \\
\text { Organization }\end{array}$ & $\begin{array}{l}\text { Sebagai pakar dan } \\
\text { akademisi, pendo- } \\
\text { rong adanya mata } \\
\text { kuliah MPKT (pen- } \\
\text { didikan integritas) } \\
\text { di skala Universitas } \\
\text { Indonesia, penggiat } \\
\text { pencegahan plagia- } \\
\text { risme di institusi } \\
\text { pendidikan. }\end{array}$ & $\begin{array}{l}\text { Pandangan ger- } \\
\text { akan antikorupsi } \\
\text { di institusi pergu- } \\
\text { ruan tinggi dan } \\
\text { upaya pencega- } \\
\text { han dan gerakan } \\
\text { antikorupsi. }\end{array}$ & \\
\hline 6. & $\begin{array}{l}\text { Pimpinan } \\
\text { Fakultas } \\
\text { Kesehatan } \\
\text { Masyarakat }\end{array}$ & $\begin{array}{l}\text { Pemangku kebijakan } \\
\text { yang mampu mem- } \\
\text { berikan pengaruh } \\
\text { terhadap arah kebi- } \\
\text { jakan internalisasi } \\
\text { integritas kepemimp- } \\
\text { inan antikorupsi di } \\
\text { Fakultas Kesehatan } \\
\text { Masyarakat }\end{array}$ & $\begin{array}{l}\text { Pandangan terkait } \\
\text { korupsi di sek- } \\
\text { tor kesehatan } \\
\text { dan kontribusi } \\
\text { perguruan tinggi } \\
\text { terhadap gerakan } \\
\text { antikorupsi. }\end{array}$ & \\
\hline 7. & $\begin{array}{l}\text { Kepala } \\
\text { Badan } \\
\text { PPSDM } \\
\text { Kementerian } \\
\text { Kesehatan }\end{array}$ & $\begin{array}{l}\text { Salah satu pengam- } \\
\text { bil keputusan regu- } \\
\text { lasi SDM Kesehatan } \\
\text { di Indonesia. }\end{array}$ & $\begin{array}{l}\text { Pandangan regu- } \\
\text { lasi terkait gerakan } \\
\text { antikorupsi pada } \\
\text { tenaga kesehatan, } \\
\text { kriteria rekrut- } \\
\text { men tenaga } \\
\text { kesehatan, dan } \\
\text { upaya pencegahan } \\
\text { korupsi pada SDM } \\
\text { kesehatan. }\end{array}$ & $\begin{array}{l}\text { Belum } \\
\text { melakukan } \\
\text { wawancara } \\
\text { meskipun } \\
\text { telah } \\
\text { bersurat } \\
\text { karena } \\
\text { belum ada } \\
\text { jadwal } \\
\text { wawancara } \\
\text { yang } \\
\text { diberikan. }\end{array}$ \\
\hline
\end{tabular}




\begin{tabular}{|c|c|c|c|c|}
\hline 8. & $\begin{array}{l}\text { Mantan Pe- } \\
\text { jabat Tinggi } \\
\text { periode } \\
\text { 2004-2009 } \\
\text { yang pernah } \\
\text { tersangkut } \\
\text { korupsi. }\end{array}$ & $\begin{array}{l}\text { Pemimpin di sektor } \\
\text { kesehatan yang telah } \\
\text { menjalani masa } \\
\text { kepemimpinannya } \\
\text { di sektor kesehatan } \\
\text { yang mampu meng- } \\
\text { gambarkan kekhasan } \\
\text { sektor kesehatan dan } \\
\text { pandangan korupsi } \\
\text { di sektor kesehatan. }\end{array}$ & $\begin{array}{l}\text { Pandangan tentang } \\
\text { kepemimpinan di } \\
\text { sektor kesehatan, } \\
\text { karakteristik } \\
\text { kepemimpinan } \\
\text { antikorupsi di } \\
\text { sektor kesehatan, } \\
\text { dan upaya gerakan } \\
\text { antikorupsi di sek- } \\
\text { tor kesehatan. }\end{array}$ & \\
\hline 9. & $\begin{array}{l}\text { Kepala } \\
\text { Puskesmas } \\
\text { Kecamatan }\end{array}$ & $\begin{array}{l}\text { Pemimpin } \\
\text { dan pelaku } \\
\text { kepemimpinan di } \\
\text { sektor kesehatan } \\
\text { dengan status } \\
\text { Puskesmas BLUD. }\end{array}$ & $\begin{array}{l}\text { Menggali nilai- } \\
\text { nilai integritas } \\
\text { kepemimpinan } \\
\text { di sektor } \\
\text { kesesahatan. }\end{array}$ & \\
\hline 10. & $\begin{array}{l}\text { Kepala } \\
\text { Puskesmas } \\
\text { Kelurahan }\end{array}$ & $\begin{array}{l}\text { Pemimpin di sektor } \\
\text { kesehatan dengan } \\
\text { jabatan fungsional } \\
\text { di Puskesmas } \\
\text { Kelurahan. }\end{array}$ & $\begin{array}{l}\text { Menggali nilai- } \\
\text { nilai integritas } \\
\text { kepemimpinan } \\
\text { di sektor } \\
\text { kesesahatan. }\end{array}$ & \\
\hline 11. & $\begin{array}{l}\text { Direktur } \\
\text { Rumah Sakit }\end{array}$ & $\begin{array}{l}\text { Pelaku } \\
\text { kepemimpinan di } \\
\text { rumah sakit. }\end{array}$ & $\begin{array}{l}\text { Menggali nilai- } \\
\text { nilai integritas } \\
\text { kepemimpinan di } \\
\text { sektor kesehatan. }\end{array}$ & \\
\hline 12. & $\begin{array}{l}\text { Manajer } \\
\text { Rumah } \\
\text { Sakit Umum } \\
\text { Daerah }\end{array}$ & $\begin{array}{l}\text { Pelaku manajemen } \\
\text { di rumah sakit. }\end{array}$ & $\begin{array}{l}\text { Menggali nilai- } \\
\text { nilai integritas } \\
\text { kepemimpinan di } \\
\text { sektor kesehatan. }\end{array}$ & \\
\hline 13 & $\begin{array}{l}\text { Biro } \\
\text { Kepega- } \\
\text { waian } \\
\text { Kementerian } \\
\text { Kesehatan }\end{array}$ & $\begin{array}{l}\text { Pimpinan Biro } \\
\text { Kepegawaian yang } \\
\text { menetapkan dan } \\
\text { melaksanakan proses } \\
\text { penempatan dan } \\
\text { penetapan jabatan/ } \\
\text { kepangkatan di Ke- } \\
\text { meterian Kesehatan }\end{array}$ & $\begin{array}{l}\text { Menggali per- } \\
\text { aturan/regulasi } \\
\text { berkaitan proses } \\
\text { rekrutmen dan } \\
\text { penempatan serta } \\
\text { penetapan jabatan }\end{array}$ & $\begin{array}{l}\text { Belum } \\
\text { melakukan } \\
\text { wawancara } \\
\text { meskipun } \\
\text { telah } \\
\text { bersurat } \\
\text { karena } \\
\text { belum ada } \\
\text { jadwal } \\
\text { wawancara } \\
\text { yang } \\
\text { diberikan }\end{array}$ \\
\hline
\end{tabular}

Dilakukan analisis isi (content analysis) terhadap hasil wawancara untuk menetapkan fenomena tematik. Analisis dipertajam dengan pemanfaatan data sekunder, melakukan kajian literatur dan 
analisis berita tentang korupsi dari berbagai media masa sekaligus sebagai triangulasi dalam upaya menjaga validitas data.

Adapun proses penelitian dan pengumpulan data dilakukan deng-an tahapan: a). analisis data sekunder dan berbagai kajian literatur termasuk analisis berita korupsi relevan di media masa untuk menggali konsep dan implementasi integritas kepemimpinan antikorupsi di Indonesia. b). Wawancara mendalam dilakukan dengan menggunakan pedoman wawancara yang kemudian hasil wawancara disusun dalam sebuah matriks setelah dilakukan analisis isi (content analysis).

Keseluruhan tahap penelitian dilakukan dengan memperhatikan aspek etika dalam penelitian dan penulisan ilmiah. Penghormatan terhadap aspek etik berawal sejak penyusunan proposal dengan pencantuman sumber referensi, penyiapan perizinan dalam pengambilan data, wawancara dan survei, serta persetujuan setelah penjelasan penelitian dengan informed consent. Telah dilakukan proses kaji etik dengan mempresentasikan proposal penelitian dan mendapatkan peneguhan yang tertuang dalam surat lolos kaji etik nomor 74/UN2. F10/PPM.00.02/2017.

\section{B. PEMBAHASAN}

\section{Regulasi Terkait Integritas Kepemimpinan di Sektor Kesehatan: Bagian dari Kompetensi Dasar}

Analisis konsep tentang integritas kepemimpinan di sektor kesehatan diawali dengan melakukan kajian (desk study) terhadap berbagai regulasi terkait. Fokus analisis diarahkan terhadap berbagai peraturan yang memuat persyaratan menduduki jabatan, penerimaan pegawai dan posisi strategis di sektor kesehatan. Memiliki kedudukan sebagai pegawai pemerintahan membuka kesempatan untuk penyalahgunaan. Tidak hanya di awal penerimaan sebagai calon pegawai negeri sipil (CPNS), ketika akhirnya seseorang ditetapkan sebagai pegawai negeri sipil (PNS), proses jenjang karir menuju posisi dan jabatan strategis juga dapat menjadi tantangan bagi 
integritas kepemimpinan antikorupsi di sektor kesehatan.

Proses rekrutmen dapat menjadi titik bermulanya korupsi. Regulasi tentang kesempatan melamar menjadi PNS terdapat dalam Peraturan Pemerintah Republik Indonesia Nomor 11 Tahun 2017 tentang Manajemen Pegawai Negeri Sipil Pasal 23. Upaya pencegahan telah ada sebagaimana uraian Pasal 23 ayat (1), yaitu salah satu syarat melamar menjadi PNS, yaitu tidak pernah dipidana. Juga dilakukannya sumpah janji saat akhirnya diangkat sebagai PNS untuk menaati segala peraturan perundang-undangan dan senantiasa menjunjung tinggi kehormatan negara, pemerintah, dan martabat pegawai negeri sipil. Nilai yang lebih jelas ternyatakan pada Pasal 54 tentang persyaratan diangkat dalam jabatan seorang PNS, yaitu harus memiliki integritas dan moralitas yang baik. Juga pada Pasal 58 tentang tugas yang dijalankan sebaik-baiknya, dengan rasa penuh tanggung jawab dan menjaga integritas, tidak menyalahgunakan kewenangan, serta menghindarkan diri dari perbuatan tercela (PP No 11 Tahun 2017).

Pentingnya pemastian nilai dan kompetensi integritas kepemimpinan antikorupsi dalam berbagai peraturan kepegawaian juga diungkapkan oleh seorang informan dalam wawancara mendalam. Informan tersebut menyoroti Peraturan Menteri Kesehatan Republik Indonesia nomor 971/MENKES/PER/XI/2009 tentang Standar Kompetensi Pejabat Struktural Kesehatan, menyatakan pada Bab III Pasal 3 bahwa standar kompetensi pejabat struktural kesehatan terdiri dari kompetensi dasar, kompetensi bidang dan kompetensi khusus.

$$
\begin{aligned}
& \text { “...dalam Permenkes } 971 \text { tidak ada klasifikasi kepemimp- } \\
& \text { inan dan integritas." }
\end{aligned}
$$

Kompetensi dasar sebagaimana dimaksud dalam Pasal 4 ayat (1) meliputi: integritas, kepemimpinan, perencanaan, penganggaran, pengorganisasian, kerja sama, dan fleksibel. Artinya, memang integritas termaktub sebagai bagian dari kompetensi dasar. Adapun untuk kompetensi bidang sebagaimana dimaksud dalam Pasal 4 ayat (2) juga tidak mencantumkan nilai integritas kepemimpinan 
antikorupsi, mungkin merupakan nilai tersirat yang terkandung dalam "profesional". Demikian pula dengan kompetensi khusus sebagaimana dimaksud dalam Pasal 4 ayat (3), meliputi: pendidikan; pelatihan; dan/atau pengalaman jabatan.

Integritas menjadi salah satu kompetensi dasar, meskipun tidak tercantum sebagai "integritas kepemimpinan antikorupsi". Namun demikian, bila dipelajari syarat khusus direktur dan wakil direktur yang menyatakan "telah mengikuti pelatihan perumahsakitan sistem akuntabilitas", maka nilai integritas antikorupsi dapat terkandung di dalamnya. Hal serupa berlaku untuk posisi strategis (Kepala dan Sekretaris Dinas Kesehatan, Kompetensi Kepala Bidang dan/atau Bagian, Kepala Seksi dan/atau Kepala Subbagian, Pejabat struktural puskesmas, dan Pejabat struktural Unit Pelaksana Teknis/Unit Pelaksana Teknis Daerah (UPT/UPTD). Persyaratan kompetensi khusus juga belum eksplisit mencantumkan kompetensi antikorupsi. Peraturan tersebut tidak pula dilengkapi dengan petunjuk pedoman atau aturan teknis yang mencantumkan indikator formal dan terukur tentang kepemimpinan antikorupsi.

\section{Analisis Kasus Korupsi di Sektor Kesehatan}

Analisis terhadap berbagai regulasi berkait dengan penempatan dan penetapan jabatan bagi pejabat pemerintah memperlihatkan bahwa nilai-nilai integritas dan kompetensi kepemimpinan antikorupsi telah ada sebagai nilai-nilai dasar yang tersirat. Jadi tidak dinyatakan secara eksplisit sebagai standar kompetensi pejabat struktural kesehatan. Berlaku efektif atau tidaknya berbagai regulasi yang mencantumkan tentang kompetensi integritas kepemimpinan antikorupsi di Indonesia dapat tercermin dari berbagai kasus kejadian korupsi di sektor kesehatan seperti yang tergambar pada tabel 2: 
Tabel 2. Kasus Korupsi di Sektor Kesehatan dari Berbagai Media Elektronik

Tahun 2014 dan 2017

\begin{tabular}{|c|c|c|c|}
\hline \multicolumn{2}{|c|}{ Tingkat } & \multirow[t]{2}{*}{ Bentuk Korupsi } & \multirow{2}{*}{$\begin{array}{l}\text { Besar Keru- } \\
\text { gian }\end{array}$} \\
\hline Pusat & Daerah & & \\
\hline $\begin{array}{l}2 \text { Menteri } \\
\text { Kesehatan }\end{array}$ & $\begin{array}{l}7 \text { Anggota } \\
\text { DPR/ } \\
\text { DPRD }\end{array}$ & Pengadaan Alat kesehatan & $\begin{array}{l}\text { Rp 249,1 } \\
\text { miliar }\end{array}$ \\
\hline $\begin{array}{l}2 \text { Dirjen } \\
\text { Kemkes }\end{array}$ & $\begin{array}{l}3 \text { Kepala } \\
\text { Daerah }\end{array}$ & Posisi lelang jabatan & $\begin{array}{l}\text { Sebanyak } 93 \\
\text { kasus dengan } \\
\text { nilai kerugian } \\
\text { negara Rp } \\
512,9 \text { miliar }\end{array}$ \\
\hline $\begin{array}{l}2 \text { Menteri } \\
\text { Kesehatan }\end{array}$ & $\begin{array}{l}31 \text { Kepala } \\
\text { Dinas Ke- } \\
\text { sehatan }\end{array}$ & Obat & $\begin{array}{l}\text { S e k u r a } \mathrm{ng}- \\
\text { kurangnya Rp } \\
6,8 \text { miliar }\end{array}$ \\
\hline $\begin{array}{l}\text { Mantan Sekre- } \\
\text { taris Jenderal } \\
\text { (kini Kemente- } \\
\text { rian Kesehatan }\end{array}$ & $\begin{array}{l}14 \text { Direk- } \\
\text { tur Rumah } \\
\text { Sakit }\end{array}$ & $\begin{array}{l}\text { Pengadaan alat kesehatan untuk } \\
\text { KLB }\end{array}$ & Rp 6,2 Miliar \\
\hline \multicolumn{4}{|c|}{ Sumber : (Beritasatu.com, 2014) } \\
\hline \multirow[t]{5}{*}{$\begin{array}{l}6 \text { Direksi dan } \\
\text { Karyawan } \\
\text { BUMN/BUMD }\end{array}$} & $\begin{array}{l}5 \text { Kepala } \\
\text { Puskes- } \\
\text { mas }\end{array}$ & $\begin{array}{l}\text { Pembangunan/rehabilitasi rumah } \\
\text { sakit dan puskesmas } \\
\text { Pembangunan laboratorium }\end{array}$ & Rp 2,67 miliar \\
\hline & $\begin{array}{l}1 \text { Guber- } \\
\text { nur }\end{array}$ & Jaminan kesehatan & $\begin{array}{l}\text { Lebih dari Rp } \\
500 \text { juta }\end{array}$ \\
\hline & 5 Bupati & $\begin{array}{l}\text { Pembangunan gedung rawat inap } \\
\text { anggrek dan jembatan penghubung } \\
\text { di lingkungan RSUP }\end{array}$ & \\
\hline & 1 Walikota & $\begin{array}{l}\text { Space alat medis, yakni yang se- } \\
\text { mestinya produk luar negeri diganti } \\
\text { produk dalam negeri. }\end{array}$ & \\
\hline & $\begin{array}{l}1 \text { Wakil } \\
\text { Walikota }\end{array}$ & $\begin{array}{l}\text { Pengadaan alat medis dan kesehatan } \\
\text { Rumah Sakit Daerah Kabupaten }\end{array}$ & \\
\hline
\end{tabular}

Sumber: ICW, 2017

Selain Kemenkes, korupsi kesehatan juga terjadi di lembaga kesehatan lain seperti Dinas Kesehatan tongkat provinsi/kabupaten/ kota, rumah sakit dan puskesmas. Berdasarkan pemantauan Indonesian Coruuption Wathch (ICW), sebanyak 46 kasus korupsi terjadi 
di Dinkes Provinsi/Kabupaten/Kota, 55 kasus di rumah sakit, dan 9 kasus di puskesmas seluruh Indonesia. Total kerugian negara di tiga lembaga kesehatan ini mencapai Rp 210,1 miliar (ICW, 2017).

\section{Konsep dan Kriteria Kepemimpinan Antikorupsi Sek- tor Kesehatan}

\section{1. Kondisi Serupa dengan Sektor Lain dalam Pola Generik}

Kondisi memprihatinkan dari banyaknya kasus korupsi yang telah terjadi sesungguhnya memberi isyarat tentang kemungkinan belum cukup besarnya perhatian tentang integritas kepemimpinan antikorupsi di sektor kesehatan. Para informan menyampaikan keprihatinan tentang hal ini, meskipun dipandang bahwa korupsi bukanlah hal baru, namun muncul lebih banyak dan semakin cepat terdeteksi di era ini.

"Korupsi seperti kentut, bunyinya tidak kedengaran, baunya kemana-mana."

"Potensi korupsi di kesehatan besar sekali."

Korupsi hampir menjadi kelaziman di institusi pemerintahan semua sektor dan berlangsung dengan pola umum atau generik, misalnya pada proses kenaikan jabatan atau promosi untuk posisi strategis. Kondisi yang pula terjadi di sektor kesehatan. Namun disadari bahwa untuk sektor kesehatan yang menyangkut hajat hidup banyak orang, bahkan bagian dari hak dasar manusia, bahaya yang ditimbulkan atau dampak kerusakan akan amat besar.

"Sistem korupsi sudah sangat luas contoh luas untuk nepotisme corruption seperti naik jabatan. Artinya hal yang secara generik juga terjadi di sektor umum dan juga kesehatan."

“...Terjadi dalam berbagai bentuk..... yang menjadi korban adalah manusia. Perhatian menjadi penting karena kesehatan memberikan dampak langsung kepada manusia."

Pandangan tersebut menguatkan fakta kekhususan sektor kesehatan yang memperbesar faktor-faktor risiko, seperti asimetri distribusi informasi, ketidakpastian mekanisme pasar, dan besarnya 
pengeluaran publik, serta kenyataan betapa vital bagi masyarakat karena menyangkut hajat hidup dan kehidupan. Ditambah lagi dengan adanya ketidakpastian dalam pelayanan kesehatan, misalnya saja ketidaktahuan kapan ia akan butuh pelayanan rumah sakit dan berapa biaya yang akan ia keluarkan, maka dampak korupsi di sektor kesehatan menjadi amat besar.

\section{2. Korupsi Tidak Selalu dengan Motif Kepentingan Pribadi dan Kerap Terjadi sebagai Bentuk Kelalaian}

Hal menarik lain yang disampaikan oleh beberapa informan adalah bahwa korupsi di sektor kesehatan tidaklah selalu merupakan bentuk kejahatan yang dilakukan dengan motif keuntungan dan semata kesengajaan untuk memperkaya diri. Seringkali kasus korupsi terjadi sebagai kelalaian, "ketidakpedulian", ketidakcermatan dan ketidakpahaman dalam menjalankan administrasi, sehingga akhirnya terjebak dan menjerumuskan seorang tenaga medis dalam tindak korupsi. Seorang informan yang terlibat dalam kasus korupsi hingga akhirnya dijatuhkan vonis tetap tidak memahami bahwa apa yang pernah dilakukannya untuk merespons situasi sulit telah dipandang sebagai bagian dari tindak korupsi. Artinya, korupsi di sektor kesehatan sangat mungkin merupakan bentuk tindakan kelalaian atau kesalahan prosedur administratif yang tidak dapat dipertanggungjawabkan secara hukum dan bukan didorong oleh motif utama keuntungan pribadi.

"Sektor kesehatan banyak dokter yang cenderung tidak peduli administrasi yang seringnya terjadi korupsi karena salah manajemen. Korupsi terjadi tidak selalu karena keinginan memperkaya diri tapi bisa juga karena terjerumus."

"Ketika terjadi korupsi, bukan dari X sebagai dokter namun dari $\mathrm{X}$ sebagai fungsi managemen walaupun terjadi juga dokter yang mengakali, tapi bisa juga karena sistem yang tidak rasional." 
"Semua kesaksian di pengadilan tidak ada yang bisa membuktikan ('saya bersalah': red,), tapi yaa, akibatnya saya harus tanggung dan terima seperti ini."

\section{3. Nilai Moral yang Bergeser dan Berubah}

Meskipun muncul pandangan bahwa kerapkali kejadian korupsi adalah akibat kelalaian dan ketidakpahaman serta bukan upaya sengaja memperkaya diri, namun ada pula pandangan yang justru berbeda. Seorang informan lain menegaskan bahwa sektor kesehatan merupakan sektor yang memiliki potensi amat besar untuk terjadinya kejahatan korupsi oleh beberapa penyebab. Besarnya jumlah dana yang harus dikelola karena Kementerian Kesehatan menempati posisi lima besar anggaran, menciptakan peluang terjadinya tindak korupsi. Namun yang lebih penting, justru adanya pergeseran nilainilai moral dan pengabdian di antara para pejabat atau pimpinan di sektor kesehatan yang menjadi cikal bakal berkembangnya korupsi di sektor kesehatan.

"Sejarah -pembangunan peradaban di Indonesia- banyak dibangun oleh dokter, namun bergeser saat ini. Awalnya datang dengan konsep apa manfaat saya untuk orang lain. Kini menjadi langka dan bergeser..."

\section{4. Makna Integritas Kepemimpinan Antikorupsi}

Penggalian tentang pengertian integritas kepemimpinan antikorupsi menunjukkan selalu ada nilai-nilai universal yang muncul seperti tanggung jawab, kejujuran, keterbukaan, transparansi. Namun ada pula yang menekankan kekhususan untuk sektor kesehatan, yaitu ketangguhan, rasa takut pada Tuhan, kebermanfaatan dan keberpihakan.

“... menurut saya sih konsep integritas berarti semacam loyalitas, kemudian tanggung jawab untuk meminimalisir atau memperkecil terjadinya korupsi. Sehingga seseorang punya benteng diri. Kalau kita bekerja untuk ibadah, maka pasti tidak ke arah korupsi/ pasti akan jujur, transparan, juga yaa akuntabel dan yang pasti juga amanah, jadi bisa dipercaya." 
"Jujur ya yang pasti ya, jujur, keterbukaan ya kan, transparansi terus dia juga harus bertanggung jawab dengan apa yang dia lakukan kan, terus juga kan menjadikan contoh untuk bawahannya dan juga ada kerjasama tim ya yang harus dibangun di situ."

"Datang dengan konsep apa manfaat hidup saya untuk orang lain (value). Pendidikan agama menumbuhkan rasa takut pada $\mathrm{Tu}-$ han. Yang kini bergeser menjadi takut pada sistem."

Oleh karena itu, nilai integritas kepemimpinan yang harus ada untuk pegawai atau pejabat di sektor kesehatan seperti yang tergambar pada tabel 3 .

Tabel 3. Nilai Integritas Kepemimpinan Antikorupsi

\begin{tabular}{|c|c|c|}
\hline Informan & $\begin{array}{l}\text { Konsep Nilai-nilai } \\
\text { Integritas Kepe- } \\
\text { mimpinan An- } \\
\text { tikorupsi }\end{array}$ & $\begin{array}{l}\text { Integritas Kepemimpinan } \\
\text { (Leader, 2014) }\end{array}$ \\
\hline $\begin{array}{l}\text { Pakar dan Aka- } \\
\text { demisi Kesehatan }\end{array}$ & $\begin{array}{l}\text { Rasa takut pada Tuhan } \\
\text { Kebermanfaatan } \\
\text { Keberpihakan }\end{array}$ & $\begin{array}{l}\text { Penerimaan yaitu kesadaran diri untuk } \\
\text { mau menerima keadaan orang lain } \\
\text { sehingga tidak menilai, mengkritik, } \\
\text { mendiskreditkan, mendiskriminasi } \\
\text { ataupun membuat pihak lain merasa } \\
\text { lebih rendah kedudukannya. }\end{array}$ \\
\hline $\begin{array}{l}\text { Kepala Puskes- } \\
\text { mas Kecamatan }\end{array}$ & $\begin{array}{l}\text { Loyalitas } \\
\text { Tanggung jawab } \\
\text { Benteng diri } \\
\text { sebagai bentuk } \\
\text { ibadah }\end{array}$ & $\begin{array}{l}\text { Keterbukaan yang memiliki arti } \\
\text { kekuatan karakter untuk belajar dari } \\
\text { kesalahan perilaku sambil terus men- } \\
\text { cari perbaikan diri secara berkelan- } \\
\text { jutan. }\end{array}$ \\
\hline $\begin{array}{l}\text { Kepala Puskes- } \\
\text { mas Kelurahan }\end{array}$ & $\begin{array}{l}\text { Jujur } \\
\text { Keterbukaan } \\
\text { Transparansi } \\
\text { Bertanggung jawab }\end{array}$ & $\begin{array}{l}\text { Kejujuran yaitu selalu menyampaikan } \\
\text { secara jelas apa yang dimaksudkan } \\
\text { olehnya dengan nilai-nilai, etika dan } \\
\text { keyakinan. }\end{array}$ \\
\hline Guru Besar & $\begin{array}{l}\text { Tough and very strong } \\
\text { Berani menerima } \\
\text { risiko }\end{array}$ & $\begin{array}{l}\text { Keandalan, yaitu dengan melakukan } \\
\text { apa yang kita ucapkan. Sering kita } \\
\text { mendengar istilah keep your promise, } \\
\text { walk the talk, satu kata dalam perbua- } \\
\text { tan. Istilah tersebut menggambarkan } \\
\text { perilaku keandalan yang seharusnya } \\
\text { dimiliki oleh seorang pemimpin. }\end{array}$ \\
\hline $\begin{array}{l}\text { Pejabat Tinggi } \\
\text { Kemenkes 2004- } \\
2009\end{array}$ & $\begin{array}{l}\text { Hati nurani } \\
\text { Think out of the box } \\
\text { Keberanian }\end{array}$ & Keandalan \\
\hline
\end{tabular}

Sumber: Data Primer, 2018 
Nilai ketangguhan (tough and very strong) untuk dapat bertahan dan berjuang melawan bujukan kepentingan sempit atau kelompok, amat penting dimiliki seorang pejabat atau pimpinan di sektor kesehatan. Terutama pada negara berkembang seperti Indonesia yang belum sepenuhnya menjalankan good governance sehingga banyak celah terjadinya tindakan korupsi. Rasa takut pada Tuhan, kebermanfaatan, dan keberpihakan diharapkan akan menjadi dasar lahirnya integritas kepemimpinan antikorupsi di sektor kesehatan.

\section{5. Sistem yang Menginduksi Korupsi}

Menjadi amat relevan untuk membahas dan menggali tentang integritas kepemimpinan antikorupsi serta kemudian mewujudkannya. Karena di era desentralisasi dan Jaminan Kesehatan Nasional kini kerap terjadi kondisi yang justru mendorong terjadinya korupsi di sektor kesehatan. Berbagai kebijakan berkait dengan penyelenggaraan pelayanan kesehatan di era JKN ini telah memunculkan sistem yang tidak rasional dan menginduksi terjadinya korupsi. Kondisi ini diharapkan dapat dicegah dengan nilai-nilai kokoh kepemimpinan yang mampu membentengi para pelaku di sektor kesehatan. Hal tersebut mengemuka dalam wawancara kepada sejumlah informan.

"Sistem yang rapuh untuk mencegah korupsi. Adanya sistem yang menginduksi korupsi. Karena pemerintah dianggap tidak fair, akhirnya terjadi cara-cara untuk survive."

"Ini sektor yang punya kekhususan. Sektor kesehatan berhubungan langsung dengan masyarakat, pengadaan obat dan SDM itu yang membedakan dengan sektor lain. Di sinilah pemimpin harus membentengi dengan moral."

"Jujur, sekarang ini tetap ada peluang-peluang untuk kita korupsi, atau menyimpang, lah. Menyalahgunakan gitu. Peluang terjadinya korupsi tetap ada. Jadi kepribadian atau nilai-nilai dalam diri yang menjadi benteng. Selain sistemnya juga, harus mendukung." 


\section{6. Perlukah Memasukkan Integritas Kepemimpinan} Antikorupsi dalam Standar Kompetensi Formal bagi Pejabat Struktural?

Permenkes 971 tahun 2009 tentang Standar Kompetensi Pejabat Struktural Kesehatan menjadi gerbang penerimaan pejabat atau pemimpin di sektor kesehatan. Telah disampaikan sebelumnya bahwa tidak tercantum secara eksplisit kepemimpinan antikorupsi pada regulasi tersebut. Hanya ada nilai integritas pada bagian kompetensi dasar dan kemudian keharusan mengikuti pelatihan tentang sistem akuntabilitas bagi direktur atau wakil direktur rumah sakit sebagai bagian persyaratan kompetensi khusus. Oleh karena itu, studi ini mencoba mendapatkan pandangan tentang urgensi secara khusus mencantumkan kompetensi integritas kepemimpinan antikorupsi dalam peraturan penetapan pejabat.

Keseluruhan informan menyepakati perlunya nilai integritas dan kompetensi kepemimpinan antikoupsi menjadi bagian penting dalam pertimbangan penetapan posisi jabatan struktural. Integritas kepemimpinan antikorupsi diyakini akan membentengi dan mencegah para pejabat melakukan peyalahgunaan. Namun demikian ada dua pandangan yang berbeda tentang perlunya mencantumkan secara formal dan eksplisit dalam peraturan. Sebagian informan menyatakan bahwa memang bukan hal mudah, namun pencantuman dalam regulasi tertulis menjadi penting dan perlu dilakukan. Adanya standar tertulis akan memperkuat dan memberi penekanan akan urgensinya serta menjadi penanda keseriusan upaya untuk hanya merekrut dan menempatkan calon pemimpin yang berintegritas dan antikorupsi.

"Sangat bagus bila dibuat seperti itu karena untuk sektor kesehatan, yaaa, ada kekhususan."

"Eh kalau menurut saya sih supaya jelas ya ada hitam di atas putih baiknya iya, termaktub di situ ya kan tertulis tapi juga diaplikasikan seperti itu..."

"Sebenarnya kalau melihat kondisi saat ini sebenarnya perlu, maksudnya memang paling tidak, kan, jangan sampai menjadi 
seorang pemimpin atau pejabat struktural jangan sampai karbitan yaa, maksudnya yang memang gak ngerti permasalahan ......terkait dengan korupsi. ... Tapi paling enggak kalau di peraturan Permenkes-nya ya mungkin alangkah jauh lebih baik mungkin "bunyi". Karena kan kadang beberapa abu-abu ya, tidak jelas arahnya akan kemana ..."

Sementara itu pandangan lainnya justru mempertanyakan kemungkinan mampu laksana serta tantangan untuk pelaksanaan operasional.

“... Bagaimana mengukurnya? Nah nanti baik-baik saja, ketika sudah jadi pejabat muncul aslinya. Belum lagi kalau calonnya pintar sandiwara..."

“... Bila ada track record bisa membantu. Tapi kalau pengukuran sesaat akan bias. Atau peer review ditanyakan orang sekitarnya sehingga prosesnya menjadi indigenous."

"Hanya untuk jabatan yang amat strategis yaa. Why not..? Untuk yang lain-lain, tidak mudah melaksanakannya."

\section{Upaya Sistemik Melakukan Pencegahan dan Pember- antasan Korupsi di Sektor Kesehatan}

Keseluruhan informan menyampaikan pentingnya kekokohan diri, moral, kejujuran, nilai integritas dimiliki oleh setiap individu untuk mencegahnya melakukan tindak korupsi. Upaya pencegahan korupsi harus ditanamkan sejak dini melalui pendidikan di keluarga, dan penanaman nilai-nilai agama. Pendidikan formal di sekolah dapat menguatkannya, namun penanaman di keluarga, pengajaran nilai agama dan kemudian lingkungan pergaulan (peer review) akan kuat memengaruhi. Sebagaimana disampaikan Wahyudi (2016) perubahan cara berpikir (mind set) harus diawali dengan keyakinan beragama. Apabila hati baik sebagai buah dari amal agama yang betul, maka cara berpikir (mind set) akan betul dan apabila cara berpikir betul akan melahirkan perilaku yang betul pula. Telah ada sekolah yang menyelenggarakan pendidikan dan budaya antikorupsi. Ter- 
dapat sembilan nilai-nilai antikorupsi yang menjadi nilai pembelajaran, yaitu kejujuran, kedisiplinan, tanggung jawab, keadilan, keberanian, kepedulian, kerja keras, kesederhanaan, dan kemandirian.

Integritas kepemimpinan antikorupsi merupakan nilai-nilai karakter universal yang berlaku untuk semua bidang. Namun urgensi untuk memiliki nilai-nilai integritas kepemimpinan antikorupsi di sektor kesehatan menjadi jauh lebih mendesak mengingat strategisnya sektor kesehatan karena menyangkut kepentingan orang banyak dan pula sarat dengan kepentingan politis, bahkan kerap menjadi komoditas politik. Ditambah lagi dengan kekhasan sektor kesehatan yang membutuhkan respons cepat di situasi ketidakpastian (uncertainity) mendorong pentingnya nilai-nilai integritas kepemimpinan antikorupsi sebagai karakter yang sangat perlu dimunculkan.

Hal lain yang perlu menjadi perhatian dalam upaya melahirkan integritas kepemimpinan antikorupsi adalah konteks kelembagaan, organisasi atau sistem, selain fokus pada aspek individu. Beberapa teori dan penelitian empiris pernah dilakukan untuk mengetahui penyebab korupsi pada suatu organisasi (Baucus and Near, 1991; Daboub et al., 1995; Trevino and Weaver, 2003; Vardi and Weitz, 2004). Sebagian besar studi tersebut berfokus pada faktor-faktor individu, organisasi, dan lingkungan dan menilai hubungan setiap faktor tersebut dengan korupsi secara independen. Hasilnya ternyata faktor-faktor tersebut interdependen dan penyebab korupsi dalam organisasi tidak bisa hanya ditujukan kepada salah satu faktor saja (Nieuwenboer, 2008). Standar dan sasaran kebijakan antikorupsi pun harus jelas, dan proses pembuatan keputusan tersebut dibuat secara transparan, akuntabel, dan patuh terhadap kode etik pegawai negeri (Brata, 2010).

Situasi tersebut dapat pula dijelaskan dengan konsep Edward III, sebagai kerangka analisis implementasi sebuah kebijakan. Kebijakan pencegahan korupsi adalah sebuah proses sistemik yang membutuhkan interaksi antarkomponen kebijakan. Artinya, jika regulasi penegakan pencegahan korupsi akan dilakukan, maka faktor pendukung keberhasilan sebuah kebijakan yang meliputi struktur bi- 
rokrasi, sumber daya, komunikasi, dan disposisi harus hadir secara bersama-sama. Birokrasi mendukung keberhasilan implementasi kebijakan yang bersifat kompleks dan menuntut adanya kerja sama banyak pihak. Apabila struktur birokrasi tidak kondusif terhadap implementasi suatu kebijakan, maka akan terjadi hambatan dan ketidakefektifan pelaksanaan kebijakan. Di sisi lain, sumber daya juga amat penting dan dibutuhkan sebagai mesin dan bahan bakar penggerak. Sumber daya yang dimaksud dapat berupa, "Staff, information, authority, facilities; building, equipment, land and supplies." Edward III (1980:1) juga menekankan pentingnya kecukupan sumber daya untuk terlaksananya sebuah kebijakan, "Insufficient resources will mean that laws will not be enforced, services will not be provided and reasonable regulation will not be developed."

Secara khusus tentang sumber daya manusia (SDM), para pelaku kebijakan, pejabat dan pimpinan di sektor kesehatan berperan amat penting dan menentukan efektivitas pelaksanaan upaya pencegahan korupsi. Dibutuhkan para pemimpin yang memiliki nilai-nilai integritas kepemimpinan antikorupsi dan mampu memengaruhi dan menggerakkan pelaku kebijakan atau staf lainnya untuk melaksanakan upaya pencegahan antikorupsi. Pemimpin yang mencoba melaksanakan $4 \mathrm{R}$ yaitu Renew, Reframe, Restructure, dan Revitalize di institusinya sebagai organisasi dengan ketahanan terhadap korupsi (Gouillart dan Nelly, 1995) dalam Yuliana (2015). Structure influence behavior, struktur dan lembaga yang ada akan memengaruhi staf di dalamnya untuk berperilaku antikorupsi. Menjadi pemimpin strategis yang terus belajar meningkatkan kapasitas kepemimpinan antikorupsi di dalam sebuah organisasi yang juga merupakan learning organization (organisasi pembelajar) (Senge P, 1990). Selaras dengan penjelasan Edward III tentang komponen implementasi kebijakan, yaitu sumber daya dan birokrasi serta komunikasi untuk melaksanakan upaya pencegahan korupsi.

Studi ini mendapatkan gambaran tentang sistem di sektor kesehatan yang tidak rasional dan menginduksi terjadinya korupsi. Sejalan dengan penelitian Hanevi Djasri (2016) yang menyatakan 
bahwa, "ketidaknyamanan dalam sistem kesehatan menyebabkan berbagai pihak melakukan upaya penyelamatan diri untuk bertahan hidup selama berpartisipasi dalam program JKN," termasuk di antaranya melakukan tindakan yang dapat dikategorikan sebagai penyimpangan. Kasus-kasus korupsi yang terjadi merefleksikan lubanglubang pada sistem di sektor kesehatan yang dapat mendorong atau menjerumuskan pada kejahatan korupsi. Optimalisasi keseluruhan struktur birokrasi yang terus belajar, sumber daya berupa pemimpin berintegritas antkorupsi, serta komunikasi, dan disposisi dapat menjadi upaya efektif meminimalkan sistem yang menginduksi korupsi sekaligus menguatkan implementasi kebijakan pencegahan korupsi.

\section{PENUTUP}

\section{Simpulan}

Kasus korupsi di sektor kesehatan berlangsung sama memprihatinkannya dengan kondisi di sektor lain. namun dengan dampak dan bahaya yang ditimbulkan yang jauh lebih besar karena kekhususan karakteristik sektor kesehatan. Sistem yang ada di sektor kesehatan dinilai masih menginduksi tindakan korupsi. Karena itu keberadaan para pemimpin dengan nilai integritas dan kompetensi kepemimpinan antikorupsi di sektor kesehatan, menjadi amat penting dan mendesak. Upaya pencegahan korupsi di institusi pemerintah belum optimal diberlakukan sejak awal penerimaan SDM sebagai pegawai hingga penempatan pada posisi dan jabatan berikutnya. Peraturan acuan untuk penerimaan pegawai, penilaian-penempatan pejabat struktural belum secara eksplisit mencantumkan kompetensi antikorupsi sebagai bagian dari persyaratan. Konsep kepemimpinan antikorupsi berangkat dari nilai kebermanfaatan, keinginan menolong, dan karakter "amat tangguh"/very strong (keberanian untuk bertindak, mengubah dan menerima risiko sehingga memiliki daya tahan terhadap bujukan maupun dorongan untuk melakukan korupsi). Proses penanaman nilai integritas dan kepemimpinan antikorupsi harus berlangsung sejak dini dan dibangun dari nilai-nilai 
keluarga, pendidikan agama, sekolah dan lingkungan pertemanan (peer group).

\section{Rekomendasi}

Nilai-nilai integritas dan kompetensi kepemimpinan antikorupsi sepatutnya ternyatakan dengan lebih tegas, misalnya dengan mencantumkan secara eksplisit dalam regulasi formal yang mengatur penerimaan, penempatan, dan pengangkatan kepegawaian serta penetapan jabatan strategis/pempimpin di sektor kesehatan. Hal penting selanjutnya adalah, mengoperasionalkan nilai integritas dan kompetensi antikorupsi tersebut agar lebih terukur dan dapat diaplikasikan, misalnya dengan penyusunan dan penetapan indikator dan memasukkannya dalam instrumen kompetensi. Penetapan seseorang menjadi pemimpin di sektor kesehatan semestinya mempertimbangkan kompetensi antikorupsi secara komprehensif, antara lain dengan memanfatkan asesmen mulai dari rekam jejak, penilaian rekan kerja dan atasan. Upaya sistemik dan strategis yang dapat dilakukan untuk mencegah agar sistem di sektor kesehatan tidak menginduksi terjadinya korupsi adalah membangun mekanisme kerja dengan prinsip good governance yang mengedepankan nilai akuntabilitas dan transparasi, antara lain dengan memanfaatkan dan mengintegrasikan berbagai kebijakan e-Governance (e-Purchasing/e-Katalog untuk pengadaan; operasionalisasi Vedika (Verifikasi-validasi di Kantor) untuk pelayanan kesehatan yang menggunakan BPJS), menerapkan program whistle blower (adukan penyimpangan), dan sebagainya.

\section{REFERENSI}

Ayuningtyas, Dumilah; Kebijakan Kesehatan: Prinisp dan Praktik, 2014, Raja Grasindo Pers

Beritasatu, 2014. Korupsi di Sektor Kesehatan Mencapai Rp. 594

Miliar.

http://kebijakankesehatanindonesia.net/25-berita/ berita/170-korupsi-di-sektor-kesehatan-mencapai-rp-594-miliar diakses Jumat 16 Februari 2018 pukul 14.17 WIB 
Brata, Roby A. 2010. Penyebab Kegagalan Kebijakan Antikorupsi. Dipublikasikan pada tanggal 7 April 2010. Diakses melalui: https://antikorupsi.org/id/news/penyebab-kegagalan-kebijakan-antikorupsi pada tanggal 12 April 2018.

Djasri, Hanevi, dkk.2016. Korupsi dalam Pelayanan Kesehatan di Era Jaminan Kesehatan Nasional: Kajian Besarnya Potensi dan Sistem Pengendalian Fraud.Jakarta: Komisi Pemberantasan Korupsi. Jurnal Integritas Antikorupsi Volume 2, Nomor 1, Agustus 2016.

Edward III, George C. 1980. Implementing public policy, Congresional Quertly Press.

Fauziah, Luthfi. 2016. Mengenang Kembali Sejarah Hari Pendidikan Nasional di Indonesia. http://nationalgeographic.co.id/ berita/2016/05/mengenang-kembali-sejarah-hari-pendidikannasional-di-indonesia diakses pada 12 April 2018.

Hersey, Paul. 1960. Situational Leadership. http://situational.com/ the-cls-difference/situational-leadership-what-we-do/ Diakses pada 12 April 2018.

Haikal, Husain. 2014. Kepemimpinan Lokal Sebagai Pilar Kepemimpinan Nasional. http://e- journal.metrouniv.ac.id/index. php/akademika/article/view/410 diakses 25 Oktober 2017

Hanf, M., Van-Melle, A., Fraisse, F., Roger, A., Bernard, C., \& Nacher, M. (2011). Corruption kills: Estimating the global impact of corruption on children deaths. PLoS One, 6(11) doi:http:// dx.doi.org/10.1371/journal.pone.0026990

ICW. 2017. Tren Korupsi Kesehatan: Obyek Korupsi Kesehatan Bergeser Dari Korupsi Obat Ke Korupsi Jaminan Kesehatan. https://antikorupsi.org/id/news/tren-korupsi-kesehatan-obyekkorupsi-kesehatan-bergeser-dari-korupsi-obat-ke-korupsijaminan diakses Jumat 16 Februari 2018 Pukul 15.33

Kaufmann, Daniel. 2005. Myths and Realities of Governance and Corruption. Dipublikasikan pada tanggal 8 April 2008. MPRA Paper No. 8089 20:48. Diakses melalui: https://mpra.ub.unimuenchen.de/8089/1/MPRA_paper_8089.pdf pada 12 April 2018. 
Leadership Inc. 2014. Integritas Kepemimpinan. http://web.leadership-inc.co.id/integritas- kepemimpinan/ diakses 24 Oktober 2017

Mackey et al. 2016. The Disease of Corruption: Views on How To Fight Corruption to Advance 21st Century Global Health Goals. BMC Medicine. 2016; 14:149.

Nguyen et al. 2015. Citizen Participation in City Governance Experiences from Vietnam. Public Administration and Development, Vol.35 No. 1, pp.34-45.

Nieuwenboer, Niki A; Kaptein, Muel. 2008. Spiraling Down into Corruption: A Dynamic Analysis of the Social Identity Processes that Cause Corruption in Organizations to Grow. Journal of Business Ethics. 2008; 83:133-46.

Otusanya, Olatunde J. Corruption as an Obstacle to Development in Developing Countries: A Review of Literature. Journal of Money Laundering Control; London Vol.14, Iss.4. (2011):387422.

Peraturan Pemerintah Republik Indonesia Nomor 11 Tahun 2017 tentang Manajemen Pegawai Negeri Sipil

Peraturan Menteri Kesehatan Republik Indonesia Nomor 971/ MENKES/PER/XI/2009 tentang Standar Kompetensi Pejabat Struktural Kesehatan

Senge, Peter. 1990. The Fifth Discipline: The Art and Practice of the Learning Organization. United States of America.

Sidiq. 2014. Kepemimpinan dalam Islam: Kajian Tematik Dalam Al-qur'an dan Hadist. Dialogia Vol 12 No 1 Juni 2014.

Transparency International. Global Corruption Report 2006: Corruption and Health. London and Ann Arbor: Pluto Press and Transparency International; 2006.

Van Meter, Donald S \& Van Horn, Carl E. 1975. The Policy Implementation Process: A Concentual Framework in : Administration and Society. Vol.6 No. 4. Beverly Hill : Sage.

Wahyudi, Rodi. 2016. Hubungan Perilaku Korupsi dengan Ketaatan Beragama di Kota Pekanbaru. Jakarta: Komisi Pemberantasan 
Korupsi. Jurnal Integritas Antikorupsi Volume 2, Nomor 1, Agustus 2016.

Yuliana. 2015. Analisis faktor-faktor yang terkait dengan persiapan transformasi organisasi badan perencanaan pembangunan kabupaten karawang. Jurnal Ilmiah Solusi: Kerawang. 